\title{
Studi Kebijakan Pengembangan Kawasan Pangandaran Sebagai Kawasan Strategis Pariwisata Nasional
}

\author{
Tedi Sutadi ${ }^{1}$, Eka Paramita Marsongko ${ }^{2}$ \\ Sekolah Tinggi Pariwisata Bandung, Indonesia ${ }^{1,2}$ \\ Email: tedisutedi@ stp-bandung.ac.id
}

\begin{abstract}
Pangandaran is a tourism destination has an important role in regional development at national, regional and local level. This is evident from the various policies, rules, and plans established and organized as a reference in the development of Pangandaran tourism. The development of tourism in this region is not only important for the tourism sector itself but more than that tourism development is expected to improve the welfare of society and reinforce the position of the region as a region and priority can improve the economy of the wider region. Development of tourism, products and tourism market, Pangandaran is well known both national and international levels. The appeal of the beach as the main product area is a pull factor for this region. However, the development of tourism products in the region is still not well managed and potential than the beach has not been fully developed as a supporter of the appeal.
\end{abstract}

Keywords: Tourism Development; Tourism Policies; National and International Level; Tourism Product and Market.

\begin{abstract}
Abstrak
Pangandaran adalah tujuan wisata yang memiliki peran penting dalam pembangunan daerah pada tingkat nasional, regional dan lokal. Hal ini terbukti dari berbagai kebijakan, aturan, dan rencana yang ditetapkan dan diorganisasikan sebagai rujukan dalam pengembangan pariwisata Pangandaran ?: destinasi belum mampu meningkatkan daya saing kawasan. Pengembangan pariwisata di kawasan ini tidak hanya penting untuk sektor pariwisata itu sendiri tetapi lebih dari itu pengembangan pariwisata diharapkan dapat meningkatkan kesejahteraan masyarakat dan memperkuat posisi daerah sebagai suatu daerah dan prioritas dapat meningkatkan ekonomi daerah yang lebih luas. Pengembangan pariwisata, produk dan pasar pariwisata, Pangandaran terkenal di tingkat nasional dan internasional. Daya tarik pantai sebagai area produk utama adalah faktor penarik bagi wilayah ini. Namun, pengembangan produk wisata di kawasan ini masih belum terkelola dengan baik dan potensi dari pantai belum sepenuhnya dikembangkan sebagai pendukung daya tarik.
\end{abstract}

Kata Kunci: Pengembangan Pariwisata; Kebijakan Pariwisata; Tingkat Nasional dan Internasional; Produk dan Pasar Pariwisata.

\section{A. PENDAHULUAN}

Pembangunan pengembangan potensi daya tarik wisata yang dimiliki oleh setiap daerah merupakan peluang yang dapat dimanfaatkan sebagai aspek yang dapat memperbaiki kondisi daerah yang memiliki potensi-potensi wisata tersebut. Pada era otonomi daerah, pariwisata diharapkan dapat memberikan pembangunan sektor ekonomi baik untuk pemerintah mauptm masyarakat. Provinsi Jawa Barat yang memiliki potensi besar bidang pariwisata saat ini tengah mendorong pengembangan pariwisata sebagai salah satu program unggulan daerah dengan potensi pariwisatanya, saat ini tengah memacu diri untuk mengembangkan pariwisatanya.

* Corresponding author

Received: January 01, 2017; Revised: March01, 2017; Accepted: July01, 2017 
Salah satu daya tarik wisata di Provinsi Jawa Barat yang mempunyai potensi pengembangan cukup besar, adalah Kawasan Wisata Pangandaran yang berlokasi di Kabupaten Pangandaran. Hal ini didorong didalam RIPPDA Provinsi Jawa Barat Tahun 2006 bahwa sektor pariwisata sebagai salah satu sektor unggulan yang dikembangkan dalam upaya menggerakkan roda perekonomian daerah, selain itu berdasarkan RIPPDA Provinsi Jawa Barat, dijelaskan bahwa Kawasan Pangandaran merupakan salah satu destinasi wisata yang potensial yang dikembangkan menjadi kawasan pariwisata nasional dengan memanfaatkan sumber daya alam dan sumber daya buatan untuk menciptakan alternatif daya tarik wisata di Provinsi Jawa Barat, sehingga berimplikasi terhadap perlunya upaya-upaya pengembangan strategis, komprehensif dan terpadu serta dapat memberikan manfaat yang optimal. Kegiatan Pariwisata yang dikembangkan di Provinsi Jawa Barat masih belum menemui sasaran optimis dalam pengembangan ekonomi masyarakat terutama dalam memperbesar devisa dan penyerapan tenaga kerja, namun yang menjadi alasan utama adalah untuk menghasilkan manfaat ekonomi dari masuknya devisa bagi daerah, penyerapan tenaga kerja untuk peningkatan pendapatan masyarakat dan pemerintah. Pariwisata, selain dapat menghasilkan banyak manfaat bagi daerah, juga dapat menimbulkan masalah, seperti distorsi terhadap masyarakat lokal, degradasi lingkungan, hilangnya identitas dan integritas bangsa dan kesalahpahaman. Oleh karena itu, untuk mengoptimalkan manfaat dan mengurangi berbagai masalah yang ditimbulkan dengan adanya pengembangan pariwisata, maka diperlukan perencanaan pariwisata yang berkelanjutan yang tidak hanya merencanakan pada saat kondisi sekarang, tapi juga mempertimbangkan dampak-dampak yang terjadi di masa depan. Pengembangan Kawasan Pangandaran sebagai destinasi wisata dunia, diharapkan dapat mencapai kawasan pengembangan pariwisata yang berhasil, dengan kriteria-kriteria;

1 Kawasan yang secara teknis dapat digunakan untuk kegiatan pariwisata, serta tidak mengganggu kelestarian budaya,keindahan alam dan lingkungan;

2 Kawasan yang apabila digunakan untuk kegiatan pariwisata secara ruang dapat memberikan manfaat:

3 Meningkatkan devisa dan mendayagunakan investasi;

4 Meningkatkan perkembangan pembangunan lintas sektor dan sub sektor serta kegiatan ekonomi sekitarnya;

5 Tidak mengganggu fungsi lindung;

6 Tidak mengganggu upaya pelestarian sumber daya alam;

7 Meningkatkan pendapatan ma syarakat;

8 Meningkatkan pendapatan nasional dan daerah;

9 Meningkatkan kesempatan kerja;

10 Melestarikan budaya;

11 Meningkatkan kesejahteraan masyarakat.

Pengembangan destinasi merupakan bagian integral dari pembangunan pariwisata suatu negara. Berdasarkan pada UU No. 10 Tahun 2009 tentang Kepariwisataan, yang dimaksud dengan Destinasi Pariwisata adalah kawasan geografis yang berada dalam satu atau lebih wilayah administratif yang didalamnya terdapat daya tarik wisata, fasilitas utnum, fasilitas pariwisata, aksesibilitas, serta masyarakat yang saling terkait dan melengkapi terwujudnya kepariwisataan.

Penerapan pengembangan klaster dalam pengembangan Kawasan Pangandaran sebagai destinasi wisata, harus mempertimbangkan jenis dan Karakter Objek dan Daya Tank Wisata (ODTW). Kesamaan jenis dan karakter ODTW pada suatu lokasi membuat efektif pengembangan dan pemasarannya apabila dirangkai dalam suatu jaringan keterkaitan membentuk area pengembangan pariwisata (kawasan wisata) dengan karakter spesifik. Selain itu perlu juga mempertimbangkan kesamaan Arah dan Cara

2 | Jurnal Kepariwisataan: Destinasi, Hospitalitas dan Perjalanan, Volume 1 Nomor 1, 2017: 1-9 
Pencapaian/Persiapan Perjalanan. Kesamaan arah dan cara pencapaian ke lokasi pada beberapa ODTW, menguntungkan untuk dikembangkan apabila dirangkai dalam suatu jaringan keterkaitan membentuk satu kawasan pengembangan pariwisata. Dalam hal ini koridor penghubung antar ODTW dan kawasan dalam destinasi perlu dikembangkan dengan pertimbangan kenyamanan dan keamanan bagi pengguna, serta pertimbangan terhadap aspek estetika. Hal lain yang menjadi pertimbangan adalah efisiensi waktu pencapaian. Sebaran sejumlah ODTW yang secara waktu tempuh pencapaian dimungkinkan dijangkau dalam waktu yang efisien membuat efektif apabila dirangkai dalam suatu jaringan keterkaitan membentuk satu kawasan pengembangan pariwisata. Kedudukan Sebaran Objek dan Daya Tarik Wisata Secara Geografis juga menjadi pertimbangan lainnya. Sebaran ODTW pada suatu lokasi yang secara fisik berdekatan membuat efektif apabila dirangkai dalam suatu jaringan keterkaitan yang membentuk satu zona pengembangan pariwisata.

Pembangunan kepariwisataan merupakan bagian integral dalam pembangunan nasional yang dilakukan secara sistematis, terencana, terpadu, berkelanjutan, dan bertanggung jawab dengan tetap memberikan perlindungan terhadap nilai-nilai agama, budaya yang hidup dalam masyarakat, kelestarian dan mutu lingkungan hidup, serta kepentingan nasional. Pembangunan kepariwisataan diperlukan untuk mendorong pemerataan kesempatan berusaha dan memperoleh manfaat serta mampu menghadapi tantangan perubahan kehidupan lokal, nasional, dan global. Dalam pengembangan kepariwisataan, ada asas-asas yang harus diperhatikan, yaitu asas manfaat; asas kekeluargaan; asas adil dan merata; asas keseimbangan; asas kemandirian; asas kelestarian; asas partisipatif; asas berkelanjutan; asas demokratis; asas kesetaraan; dan asas kesatuan. Dalam mencapai tujuan pembangunan kepariwisataan nasional menganut pada prinsip-prinsip:

1 Menjunjung tinggi norma agama dan nilai budaya sebagai pengejawantahan dari konsep hidup dalam keseimbangan hubungan antara manusia dan Tuhan Yang Maha Esa, hubungan antara manusia dan sesama manusia, dan hubungan antara manusia dan lingkungan;

2 Menjunjung tinggi hak asasi manusia, keragaman budaya, dan kearifan lokal; Memberi manfaat untuk kesejahteraan rakyat, keadilan, kesetaraan, dan proporsionalitas;

3 Memelihara kelestarian alam dan lingkungan hidup;

4 Memberdayakan masyarakat setempat;

5 Menjamin keterpaduan antarsektor, antardaerah, antara pusat dan daerah yang merupakan satu kesatuan sistemik dalam kerangka otonomi daerah, serta keterpaduan antar pemangku kepentingan;

6 Mematuhi kode etik kepariwisataan dunia dan kesepakatan internasional dalam bidang pariwisata; dan

7 Memperkukuh keutuhan Negara Kesatuan Republik Indonesia (NKRI).

\section{B. METODE PENELITIAN}

Metode yang digunakan dalam Penelitian ini adalah deskriptif dengan pendekatan metodologis yang bersifat analisis kualitatif melalui pendekatan komprehensif. Metode penelitian deskriptif adalah metode penelitian yang melukiskan variabel demi variabel, satu demi satu (Hasan, 2002:13).

\section{Populasi dan Sampel Penelitian}

Populasi yang diambil dalam penelitian ini adalah pelaku yang terkait dengan kegiatan kepariwisataan Kawasan Pangandaran, yakni pihak pengelola, pengusaha pariwisata dan masyarakat, termasuk pengunjung kawasan tersebut. Dad populasi tersebut kemudian diambil sampel yang merupakan sebagian dari populasi yang mewakili keseluruhan populasi dalam mengungkapkan suatu keadaan lokasi yang diteliti. 


\section{Teknik Penarikan Sampel}

Dalam studi ini strategi pengambilan sampel yang digunakan adalah Non- Probability Sampling, yng berarti pernyataan yang diambil dari sampel hanya pada saat melakukan penelitian. Hal ini menyatakan bahwa data penelitian hanya mewakili beberapa waktu (pada saat penelitian). Selain itu tidak ada batasan dalam pengambilan sampel/jumlah responden.

Maka untuk mendapatkan data yang bersifat kualitatif, teknik sampling yang digunakan adalah purposive sampling method, yaitu pengambilan sampel yang terpilih menurut ciri-eiri khusus yang dimilikinya atau berdasarkan penilaian tertentu. Sampel berdasarkan representasi sampel dalam sebuah populasi, tetapi berdasarkan kebutuhan data atau informasi yang hendak dikumpulkan. Teknik ini digunakan untuk menentukan Individu yang dianggap dapat menjadi narasumber potensial dalam perencanaan pariwisata, para pengelola kegiatan kepariwisataan, serta masyarakat lokal menjadi sumber informasi/ nara sumber penelitian.

\section{Teknik Pengumpulan Data}

Data yang diperlukan dalam studi penyusunan Master Plan ini adalah data primer dan data sekunder mengenai kepariwisataan di Kawasan Pangandaran, maka prosedur pengumpulan data dilakukan dengan menggunakan pendekatan survey. Menurut Hasan (2002:82), data primer adalah data yang diperoleh atau dikumpulkan langsung di lapangan oleh tim studi. Data primer ini disebut juga data asli atau data baru. Sedangkan data sekunder adalah data yang diperoleh atau dikumpulkan oleh orang yang melakukan studi dari sumber-sumber yang telah ada. Adapun teknik pengumpulan data yang digunakan adalah sebagai berikut:

\section{Observasi}

Observasi yang digunakan dalam studi ini adalah observasi berstruktur, yaitu observasi dimana pengamat dalam melakukan observasinya menggunakan pedoman pengamatan melalui daftar periksa (checklist).Tujuan dad observasi yaitu untuk memperoleh data primer, adapun data yang diperoleh merupakan informasi mengenai keadaan aktual baik fisik maupun non-fisik dari lokus studi dengan melakukan pengamatan langsung ke wilayah perencanaan bidang kepariwisataan termasuk Daya Tarik Wisata (DTW) dan pusat_-pusat usaha pariwisata baik yang bersifat aktual maupun potensial.

\section{Wawancara}

Teknik wawancara yang digunakan dalam penelitian ini adalah wawancara berstruktur, yaitu teknik wawancara dimana pewawancara menggunakan (mempersiapkan) daftar pertanyaan atau daftar isian sebagai pedoman saat melakukan wawancara yang ditujukan pada dinas-dinas dan lembagalembaga terkait, para pelaku usaha, tokoh masyarakat serta masyarakat setempat. Wawancara dilakukan dengan menggunakan pedoman wawancara.

Wawancara terstruktur dilaksanakan secara mendalam (isidepth interview) kepada beberapa informan kunci (key-informan), yaitu:

1 Instansi pemerintah yang secara langsung maupun tidak langsung terlibat dalam kegiatan kepariwisataan, antara lain instansi kepariwisataan serta instansi terkait lainnya yang terdapat di Kawasan Pangandaran.

2 Asosiasi kepariwisataan dan yang terkait yang terdapat di Kawasan Pangandaran.

$4 \mid \overline{\text { Jurnal Kepariwisataan: Destinasi, Hospitalitas dan Perjalanan, Volume } 1 \text { Nomor 1, 2017: 1-9 }}$ 
3 Nara sumber yang memiliki kompetensi terhadap pengembangan pariwisata di Kawasan Pangandaran.

\section{Studi literatur}

Studi literatur ini dimaksudkan untuk memperoleh konsep-konsep yang relevan serta data sekunder yang memiliki relevansi maupun sebagai data penunjang dalam penelitian ini. Diperoleh dari berbagai literature yang terkait, laporan-laporan penelitian terdahulu, buku-buku/referensi dan datadata penting lainnya dari dinas atau instansi maupun pihak lain yang terkait.

\section{Alat Pengumpulan Data}

Penggunaan instrumen pengumpulan data sangat berhubungan erat dengan jenis metode yang digunakan. Menurut Kusmayadi \& Sugiarto (2000:85), untuk mengumpulkan data dengan satu metode dapat digunakan satu atau lebih instrumen demikian pula sebaliknya, satu instrumen dapat digunakan untuk satu atau lebih metode. Adapun alat kumpul data yang digunakan didalam penelitian ini yaitu :

\section{HASIL DAN ANALISIS}

Kebijakan pembangunan khususnya pada sektor pariwisata di Kawasan Pangandaran dilakukan dengan mempertimbangkan kondisi kawasan tersebut. Tinjauan regional ini dimaksudkan untuk memberikan gambaran peran Kawasan Pangandaran terhadap wilayah regional yang lebih luas berdasarkan kebijakan-kebijakan yang dikenakan terhadapnya, sehingga dapat diketahui prospek pengembangannya serta kontribusinya terhadap wilayah regional (seberapa penting kedudukannya dalam konteks kepariwisataan nasional dan daerah). Dalam cakupan regional maka peran Kawasan Pangandaran dapat dibagi atas peran dalam lingkup nasional dan Provinsi Jawa Barat.

\section{Kebijakan di Lingkup Nasional}

Dalam lingkup nasional, kawasan wisata pangandaran berdasarkan kepada Peraturan Pemerintah No. 50 Tahun 2011 Tentang Rencana Induk Pembangunan Kepariwisaraan Nasional masuk ke dalam De stinasi Pariwisata Nasional (DPN) dan Kawasan Strategis Pariwisata Nasional.

\section{Sebagai Destinasi Pariwisata Nasional (DPN)}

Dalam konsep pengembangan pariwisata nasional, berdasarkan Peraturan Pemerintah Nomor 50 Tahun 2011 tentang Rencana Induk Pembangunan Kepariwisataan Nasional Tahun 2010-2025, Kawasan Pangandaran termasuk ke dalam wilayah pengembangan ke 16 dari 50 Destinasi Pariwisata Nasional (DPN) Pangandaran-Nusakambangan dan Sekitarnya dengan produk andalan berupa wisata bahari pantai dan wisata ekologi pegunungan/bentang alam. Wilayah pengembangan Destinasi Pariwisata Nasional ini meliputi kawasan wisata Tasikmalaya dan sekitanyna, Pangandaran dan sekitarnya, Cilacap-Nusakambangan dan sekitarnya, Baturaden dan sekitanya serta Karst Kebumen dan sekitarnya.

Destinasi Pariwisata Nasional (DPN) ditetapkan berdasarkan kriteria:

a. Merupakan kawasan geografis dengan cakupan wilayah provinsi dan/atau lintas provinsi yang didalamnya terdapat kawasan-kawasan pengembangan pariwisata nasional,

b. Memiliki Daya Tarik Wisata yang berkualitas dan dikenal secara luas secara nasional dan internasional, serta membentuk jejaring produk wisata dalam bentuk pola pemaketan produk dan pola l.unjungan wisatawan; 
c. Memiliki kesesuaian tema Daya Tank Wisata yang mendukung penguatan daya saing;

d. Memiliki dukungan jejaring aksesibilitas dan infrastruktur yang mendukung pergerakan wisatawan dan kegiatan Kepariwisataan;

e. Memiliki keterpaduan dengan rencana sektor terkait.

Pembangunan DPN dan KSPN sebagaimana dimaksud dalam Pasal 9 dilaksanakan secara bertahap dengan kriteria prioritas memiliki:

a. Komponen destinasi yang siap untuk dikembangkan;

b. Posisi dan peran efektif sebagai penarik investasi yang strategis;

c. Posisi strategis sebagai simpul penggerak sistemik pembangunan kepariwisataan di wilayah sekitar baik dalam konteks regional maupun nasional;

d. Potensi kecenderungan produk wisata masa depan;

e. Kontribusi yang signifikan dan/atau prospek yang positif dalam menarik kunjungan wisatawan mancanegara dan wisatawan nusantara dalam waktu yang relatif cepat;

f. Citra yang sudah dikenal secara luas;

g. Kontribusi terhadap pengembangan keragaman

h. Produk wisata di indonesia; dan

i. Keunggulan daya saing internasional.

Strategi pengembangan wisata di wilayah ini adalah Pembangunan Destinasi Pariwisata Nasional yang meliputi:
a. Pengwilayahan Pembangunan Destinasi Pariwisata Nasional;
b. Pembangunan Daya Tarik Wisata
c. Pembangunan Aksesibilitas Pariwisata
d. Pembangunan Prasarana Umum, Fasilitas Umum, dan Fasilitas Pariwisata;
e. Pemberdayaan Masyarakat melalui Kepariwisataan; dan
f. Pengembangan investasi di bidang pariwisata

Strategis Pariwisata Nasional (KSPN) yaitu KPSPN Pangandaran dan sekitarnya. KSPN ditentukan dengan kriteria:
a. Memiliki fungsi utama pariwisata atau potensi pengembangan pariwisata;
b. Memiliki sumber daya pariwisata potensial untukmenjadi daya tarik wisata unggulan dan memiliki citra yang sudah dikenal secara luas;
c. Memiliki potensi pasar, baik skala nasional maupun khususnya internasional;
d. Memiliki posisi dan peran potensial sebagai penggerak investasi;
e. Memiliki lokasi strategis yang berperan menjaga persatuan dan keutuhan wilayah;
f. Memiliki fungsi dan peran strategis dalam menjaga fungsi dan daya dukung lingkungan hidup;
g. Memiliki fungsi dan peran strategis dalam usaha pelestarian dan pemanfaatan aset budaya, termasuk di dalamnya aspek sejarah dan kepurbakalaan;
h. Memiliki kesiapan dan dukungan masyarakat;
i. Memiliki kekhususan dari wilayah;
j. Berada di wilayah tujuan kunjungan pasar wisatawan utama dan pasar wisatawan potensial nasional; dan
k. Memiliki potensi kecenderungan produk wisata masa depan. 


\section{Sebagai Kawasan Strategis Pariwisata Nasional (KSPN)}

Berdasarkan Rencana Induk Pembangunan Kepariwisataan Nasional Tahun 2010-2025, Kawasan Pangandaran merupakan Kawasan Nasional (KSPN) yaitu KPSPN Pangandaran dan sekitarnya. KSPN ditentuk an dengan kriteria:

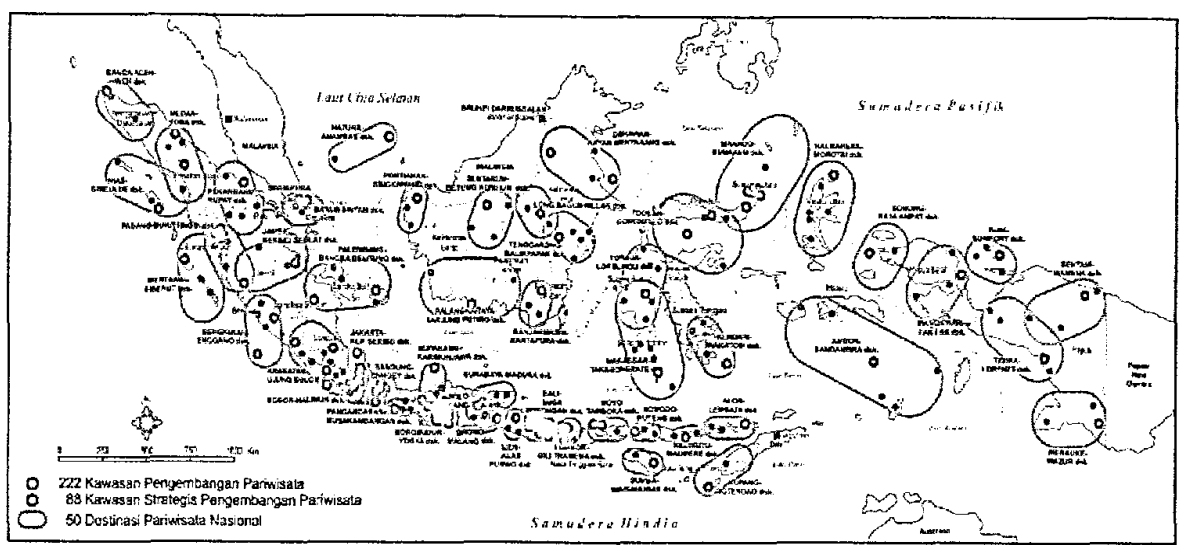

\section{Gambar 1: Pengwilayahan Pariwisata di Indonesia Berdasarkan RIPPNAS 2010-2025}

Sumber: Rencana Induk Pembangunan Kepariwisataan Nasional Tahun 2010-2025

Masuknya Kawasan Pangandaran dalam lingkup DPN dan KSPN, memberikan peluang bagi Kawasan Pangandaran dalam mengcmbangkan kawasan pariwisatanya agar dapat berkontribusi dalam pengembangan kaw asan andalan, khususnya dalam sektor pariwisata.

\section{Peran di Lingkup Provinsi Jawa Barat}

Sebagai Kawasan Wisata Unggulan B e r d a s a r kan R I P P D A J a w a Barat, Kawasan $\mathrm{P}$ angandaran termasuk dalam salah satu kaw asan wisata rekreasi pantai yang utama di Jawa Barat. Tujuan Pengembangan Pariwisata Jawa Barat adalah:

a. Menciptakan destinasi baru di Provinsi Jawa Barat yang berdaya saing.

b. Memunculkan identitas dan unsur-unsur budaya Jawa Barat yang terkait.

c. Meningkatkan kualitas dan kandungan pengetahuan dalam produk-produk pariwisata Jawa Barat.

d. Meningkatkan partisipasi masyarakat dalam kegiatanpariwisata, antara lain dengan menyediakan lapangan pekerjaan, menyediakan kesempatan investasi bagi masyarakat umum, dan sebagainya

e. Meningkatkan keterlibatan komunitas lokal dalam penyediaan prasarana dan sarana pariwisata.

f. Meningkatkan efisiensi dan akuntabilitas koordinasi antara instansi dan sektor- sektor Pariwisata

g. Meningkatkan arus perjalanan wisata di dalam Provinsi Jawa Barat, dan ke dalam Provinsi Jaw a Barat baik dari wilayah-wilayah sekitar Provinsi Jaw a Ba rat, nasional, maupuninternasional.

h. Meningkatkan penyediaan data dan informasi bagi wisatawan, serta pemasaran dan promosi pariwisata Indonesia

\section{2. Pariwisata Jawa Barat sebagai Salah Satu Bisnis Inti Provinsi}

Posisi sektor pariwisata Jawa Barat sangat penting sebagai salah satu bisnis inti Provinsi Jawa Barat. Dengan penetapan pariwisata sebagai salah satu bisnis inti, perhatian pemerintah terhadap pengembangan pariwisata bertambah besar dan pembangunan pariwisata menjadi prioritas dalam pembangunan daerah. 


\section{SIMPULAN}

Kawasan Pangandaran dan sekitarnya merupakan kawasan pengembangan pariwisata yang memiliki peran penting dalam pengembangan wilayah baik ditingkat lokal, regional, maupun nasional. Hal ini terlihat dari berbagai kebijakan, peraturan, dan rencana yang telah ditetapkan dan disusun sebagai acuan dalam upaya pengembangan kawasan Pangandaran dan sekitarnya sejauh ini belum mampu meningkatkan daya saing kawasan.

Pengembangan pariwisata di kawasan ini tidak hanya penting bagi sektor pariwisata itu sendiri, tetapi lebih dari itu pengembangan pariwisata diharapkan mampu meningkatkan kesejahteraan masyarakat serta mempertegas posisi kawasan sebagai kawasan unggulan dan prioritas yang mampu meningkatkan perekonomian wilayah yang lebih luas.

Bila ditinjau dari kondisi produk pariwisata dan pasar wisata, kawasan Pangandaran khususnya sudah cukup dikenal baik ditingkat nasional maupun internasional. Daya tarik pantai sebagai produk mama kawasan merupakan pull factor bagi kawasan ini. Namun demikian pengembangan produk pariwisata di kawasan ini masih belum tertata dengan baik dan potensi selain pantai belum sepenuhnya dikembangkan sebagai daya tarik pendukung. Pengembangan kawasan yang masih relative alami dengan suasana pedesaan yang masih asri cenderung berkembang kearah wisata massal. Kondisi kepariwisataan mengindikasikan pengembangan produk wisata yang sporadis (tourism product spontaneous development) dan tidak memiliki nilai comparative advantage. Oleh karena itu perlu disusun arahan pengembangan pariwisata yang berwawasan lingkungan untuk menghindari menurunnya kualitas lingkungan alam dan budaya sebagai sumberdaya utama kawasan.

Dari sisi sumber daya manusia dan kelembagaan serta hubungan stakeholder pembangunan pariwisata terlihat indikasi pengembangan kepariwisataan yang belum terintegrasi dan lemahnya data base sumber daya pariwisata sangat terbatas, sehingga potensi pasar yang ada belum tersegmentasi, keadaan ini dapat menyulitkan dalam menentukan posisi pasar (market tergetting and positioning) dan kegiatan pemasaran serta dalam menentukan arah pengembangan produk wisata.

\section{DAFTAR REFERENSI}

Ashworth, Gregory dan Goodall, Brian. 1990. Marketing Tourism Places. London dan New York. Roudledge.

Gunn, Clare A, 1994. Tourism Planning Basic, Concept, Cases. USA

Taylor and Francis. pasar (market targeting dan positioning) dan kegiatan pemasaran serta dalam menentukan arah pengembangan produk wisata.

Master Plan Kawasan Pangandaran dan Sekitarnya, 2008-2013, Dinas Kebudayaan dan Pariwisata Kabupaten Ciamis. 2009.

Mathieson, Alister dan Wall, Geoffrey. 1982. Tourism: Economic, Physical and Social Impacts.

Hammitt, William E. and David N. Cole, George. 1993 Sustainable 1987. Wildland Recreation Development; Local Planners. World Tourism Organization. Ecology and Management. Johner, Charles R. 1990. Tourism Wiley \& Sons.

Haris, JE \& Nelson JJ. 1993 Monitoring Tourisme from Whole Economy Perspective: A Case Sustainable Development : Philosophies. Columbus. Ohio

Hasan, M. lqbal. 2002. Pokok-pokok Materi Metodologi Penelitian dan Aplikasinva. Jakarta: Ghalia Indonesia.

Inskeep, Edward 1991. Tourism Planning: An Integrated and Sustainable Development Approach. New York, Van Nostrand Reinhold.

Kabupaten Ciamis Dalam Angka, BPS Kabupaten Ciamis, 2011.

8 | Jurnal Kepariwisataan: Destinasi, Hospitalitas dan Perjalanan, Volume 1 Nomor 1, 2017: 1-9 
Kabupaten Tasikmalaya Dalam Angka, BPS Kabupaten Tasikmalaya, 2011.

Kotler, Philip ; Haider, Donald H. dan Rein, Irving. 1993. Marketing Places: Attracting Investment Industry, and Tourism to Cities, States, and Nations. Canada. Maxwell Macmillan international. 2025

Peraturan Pemerintah No. 50 Tahun 2011 Tentang Rencana Induk Kepariwisataan Nasional 2010-200

Peraturan Daerah Nomor 22 Tahun 2010 tentang Rencana Tata Ruang Wilayah Provinsi Jawa Barat Tahun 2009-2029, Bappeda Provinsi Jawa Barat. 2010

Perubahan Rencana Pembangunan Jangka Panjang Daerah Provinsi Jawa Barat, 2005-2025, Bappeda Provinsi Jawa Barat 2010.

Peraturan Daerah Kabupaten Nomor 3 Tahun 2009 Rencana Pembangunan Menengah (RPJM) Kabupaten Ciamis Tahun 2014.

Peraturan Daerah Kabupaten Ciamis Tahun 2008 tentang Rencana Pembangunan Jangka Panjang Daerah Kabupaten Ciamis Tahun 2005-2025.

Rencana Pembangunan Jangka Menengah, Daerah Provinsi Jawa Barat Tahun 2008-2013. Bappeda Provinsi Jawa Barat. 2009.

Rencana Kerja Pemerintah Daerah Provinsi Jawa Barat Tahun 2012, Peraturan Gubemur Jawa Barat Nomor 25 Tahun 2011.

Rencana Induk Pengembangan Kepariwisataan Provinsi Jawa Barat, 2006 - 2012. Dinas Pariwisata dan Kebudayaan Provinsi Jawa Barat.

Rencana Tata Ruang Kabupaten Ciamis, Tahun 2004-2014, Bappeda Kabupaten Ciamis. Rencana Pembangunan Jangka Menengah Daerah Kabupaten Tasikmalaya Tahun 2011-2015.

Seaton, A.V., Bennet, M.M.1996. Marketing Tourism Products; Concepts, Issues, Cases. International Thomson Business Press.

Sugiarto, Endar \& Kusmayadi. 2000. Metodologi Penelitian Dalam Bidang KepariKisataan. Jakarta: PT Gramedia Pustaka Utama

Tourism Management Plan, Tourism Development Supporting Biodiversity Conservation in Pangandaran Indonesia, UNWTO, Kemenparekraf, Prov. Jawa Barat, Kabupaten Ciamis, Indecon, LWG (Pokja Pariwisata Pangandaran), 2008.

Undang Undang No.10 Tahun 2009 Tentang Kepariwisataan.

Van Bemmelen, R W. 1968. Geologi Indonesia. Jilid I, Yogyakarta: Percetakan Cepat

Williams, Allan and Shaw, Gareth. Tourism, Leisure, Nature Protection and Agri tourism; Principles. Partnerships, and Practice. European Partners for the Environment.

World Tourism Organization. 1998. Guide for Local Authorities on Developing Sustainable Tourism. Tourism and Environment Publication.

WTO. 1994. Global Tourism Forecast to the Year 2000 and Beyond: East Asia and Pasific. 